\title{
Methods of teaching inverse and incorrect problems to students in the context of informatization of education
}

\author{
Viktor S. Kornilov \\ Moscow City University \\ 29 Sheremetyevskaya St, Moscow, 127521, Russian Federation
}

\begin{abstract}
Problem and goal. Computer technologies are now widely used in applied research aimed at obtaining new scientific knowledge. These studies used the method of computer modeling and computing experiment, from which it is possible to study the properties of remote or inaccessible objects, processes and phenomena of different nature. The above mentioned is directly related to teaching students applied mathematics in general, and, in particular, to teaching students of physical and mathematical training areas inverse and ill-posed problems, which are the scientific direction of applied mathematics. It is obvious that in the process of teaching students inverse and ill-posed problems, it is advisable to use computer technologies. However, the use of computer technology should be appropriate and correct.

Methodology. The process of finding solutions to inverse and ill-posed problems is usually time-consuming, since such mathematical problems are non-linear in their formulation and may have a non-unique and unstable solution. These circumstances pose a mathematical difficulty in the proof of the theorems of existence, uniqueness and stability of solutions to inverse and ill-posed problems. Computer technologies help to overcome mathematical difficulties associated with routine transformations, analysis of information about solving such mathematical problems.

Results. Using computer technologies, students gain experience in mobile research of various inverse and ill-posed problems, as well as in identifying the capabilities of computer technologies in solving various applied mathematical problems, and develop ICT competence.

Conclusion. When using multimedia and computer technologies in the process of teaching students inverse and ill-posed problems, didactic principles of teaching are implemented, which allow students to acquire deep scientific knowledge on inverse and ill-posed problems, and develop their information culture.
\end{abstract}

Keywords: teaching inverse and ill-posed problems, computer technologies, informatization of education, student

Article history: received: 20 May 2020; accepted: 22 June 2020.

For citation: Kornilov VS. Methods of teaching inverse and incorrect problems to students in the context of informatization of education. RUDN Journal of Informatization in Education. 2020;17(4):315-322. http://dx.doi.org/10.22363/2312-8631-2020-17-4-315-322

(C) Kornilov V.S., 2020

(c) This work is licensed under a Creative Commons Attribution 4.0 International License https://creativecommons.org/licenses/by/4.0/ 


\title{
Методика обучения студентов обратным и некорректным задачам в условиях информатизации образования
}

\author{
В.С. Корнилов
}

\author{
Московский городской педагогический университет \\ Российская Федерация, 127521, Москва, ул. Шереметьевская, 29
}

\begin{abstract}
Аннотация. Проблема и иеель. Компьютерные технологии сегодня широко используются в прикладных исследованиях, направленных на получение новых научных знаний. В них применяется метод компьютерного моделирования и вычислительного эксперимента, с помощью которого возможно изучить свойства труднодоступных или недоступных человеку объектов, процессов и явлений различной природы. Это имеет непосредственное отношение к обучению студентов прикладной математике в целом и к обучению студентов физико-математических направлений подготовки обратным и некорректным задачам, которые являются научным направлением прикладной математики, в частности. Очевидно, что в процессе обучения студентов обратным и некорректным задачам целесообразно привлекать компьютерные технологии. Вместе с тем их использование должно быть уместным и корректным.

Методология. Процесс поиска решения обратных и некорректных задач, как правило, трудоемок, так как такие математические задачи по своим постановкам являются нелинейными и могут иметь неединственное и неустойчивое решение. Эти обстоятельства создают математические трудности в доказательстве теорем существования, единственности и устойчивости решений обратных и некорректных задач. Компьютерные технологии помогают преодолеть математические трудности, связанные с рутинными преобразованиями и анализом информации о решении подобных задач.

Результаты. Применяя компьютерные технологии, студенты приобретают опыт мобильного исследования разнообразных обратных и некорректных задач, выявления возможностей компьютерных технологий при решении различных прикладных математических задач, развивают ИКТ-компетентность.

Заключение. При использовании мультимедийных и компьютерных технологий в процессе преподавания студентам обратных и некорректных задач реализуются дидактические принципы обучения, которые позволяют учащимся приобрести глубокие научные знания по обратным и некорректным задачам, развить свою информационную культуру.
\end{abstract}

Ключевые слова: обучение обратным и некорректным задачам, компьютерные технологии, информатизация образования, студент

История статьи: поступила в редакцию: 20 мая 2020 г., принята к публикации: 22 июня 2020 г.

Для цитирования: Kornilov V.S. Methods of teaching inverse and incorrect problems to students in the context of informatization of education // Вестник Российского университета дружбы народов. Серия: Информатизация образования. 2020. Т. 17. № 4. C. 315-322. http://dx.doi.org/10.22363/2312-8631-2020-17-4-315-322

Problem statement. Today, in higher education institutions in the physical and mathematical fields of training, students need to master a large amount of fundamental scientific knowledge and professional competencies necessary for successful work as researchers. At the same time, unfortunately, there is not enough 
time for learning such a large amount of scientific knowledge. The use of multimedia and computer technologies in the educational process is one of the ways of existing contradictions in the system of higher education.

Currently, in higher education in the physical and mathematical areas of training, students are taught such academic disciplines as "Computer modeling", "Information technology in mathematics" and other academic disciplines, as well as various elective courses that contain computer technology.

Having mastered such academic disciplines, students understand the role of computer technologies in conducting applied scientific research, understand the role of computer modeling methodology and computational experiment in studying the world around them.

The teacher's use of multimedia and computer technologies in lectures on inverse and ill-posed problems [1-9] allows implementing a visual demonstration method of teaching [10]. Students can observe the interactive whiteboard demonstration stages of the study of inverse and ill-posed problems given theorems on existence, uniqueness and stability of solution of inverse and ill-posed problems, the numerical solution of such problems. The use of computer technologies allows students to independently implement their research and cognitive activities in laboratory classes, and develop their ICT competence.

Specialists understand ICT competence as a complex concept that characterizes the way of human life in the modern information society and includes the purposeful effective use of information and telecommunications technologies in their professional and daily activities. Many specialists use the concept of ICT competence in their work on informatization of education. The works of T.A. Boronenko, N.V. Buzhinskaya, V.F. Burmakina, V.V. Grinshkun, S.S. Kartseva, M.P. Lapchik, O.N. Novikova, L.B. Senkevich, V.S. Fedotova, E.K. Henner, and other authors are devoted to methodological aspects of ICT competence development $[11 ; 12]$.

Method of research. In the process of learning inverse and ill-posed problems, students get acquainted with modern achievements in the theory and practice of inverse and ill-posed problems, learn the methodology and approaches to their research [1-9]. In addition, students learn conceptual and mathematical information from applied and computational mathematics, mathematical methods for solving various inverse and ill-posed problems [13-15]. During the training sessions, students study model statements of inverse and ill-posed problems, applying the scheme of their research, acquire skills to prove theorems of existence, uniqueness, and stability of solutions to inverse and ill-posed problems, and gain experience in applying approximate methods for solving them using computer technologies.

Numerical methods in such cases are a mobile and effective method for studying such inverse and ill-posed problems. These numerical methods include the Newton Kantorovich method, the linearization method, optimization methods, finite difference methods, etc. The research of A.S. Alekseev, Yu.E. Anikonov, V.I. Arnold, P.N. Vabishevich, A.V. Goncharsky, V.I. Dmitriev, S.I. Kabanikhin, M.M. Lavrentiev, Yu.P. Petrov, V.G. Romanov, A.A. Samarsky, V.S. Sizikov, A.M. Cherepashchuk, A.G. Tolstoy, A.G. Yagoda and other scientists made a great contribution to the development of numerical methods for solving inverse and ill-posed problems [2;7-9]. 
Computer technologies implement analytical and numerical methods for solving differential equations, integral equations, optimization and probability problems, and other mathematical problems, as well as visualization of their solutions. Using such computer technologies, students become aware of their role in mobile research of inverse and incorrect problems, and acquire the skills to correctly select certain computer technologies for the study of a specific inverse or ill-posed problem.

Much attention is paid to the development of computational algorithms for finding approximate solutions to inverse and ill-posed problems. This circumstance explains the non-linearity of mathematical models of inverse and ill-posed problems.

Results and discussions. When teaching inverse and ill-posed problems in practical classes, students, using methods of computational mathematics, master such important mathematical concepts as finite differences, difference scheme, difference analog of a mathematical problem, grid function, interpolation of grid functions, convergence of a computational algorithm, stability of a computational algorithm, approximation error, computational error, and other concepts of computational mathematics.

Students develop the skills to apply knowledge from the theory of difference schemes and methods of computational mathematics, which they were previously taught in various physical and mathematical disciplines, when solving educational inverse and ill-posed problems.

When teaching students inverse and ill-posed problems in the context of informatization of education, much attention is paid to mathematical modeling and computational experiment. In world practice, the method of mathematical modeling and computational experiment is widely used in research of the surrounding world, its various processes and phenomena. And with the development of modern computer technologies that allow mobile research of various mathematical models, the method of mathematical modeling and computational experiment has become one of the most effective tools for understanding the surrounding reality.

The method of mathematical modeling and computational experiment is widely used in the theory of inverse and ill-posed problems. When teaching students the theory and practice of inverse and ill-posed problems, much attention is paid to the basics of mathematical modeling and computational experiment. This allows students to develop new scientific knowledge in mathematical modeling and computational experiment, which they had not studied before and could learn by attending classes in special mathematical disciplines.

When teaching students reverse and incorrect tasks, a certain contribution is made to the formation of their ecological culture.

In the course of such training, students are introduced to the concepts of humanitarization and its main provisions. Students in practical classes learn to independently analyze the obtained solutions to inverse and ill-posed problems, formulate logical conclusions about the environmental state of the environment. This can be, for example, an air space, a terrestrial environment, or a water environment. In addition, students are taught to independently apply the numerical results obtained for solving inverse and ill-posed problems in the humanitarian analysis 
of applied research. Students are also taught to analyze new information about the process or phenomenon being studied, study its properties, and comprehend the humanitarian value of this information.

Such practical exercises can be carried out by conducting humanitarianoriented training sessions on inverse and incorrect tasks. Of course, before they are held, it is necessary to conduct a mathematical and didactic analysis of the content of the educational material that is planned to be introduced to students. It is also necessary to develop a system of inverse and ill-posed problems, the solution of which is planned to be assigned to students in the classroom. Obviously, you need to think through and formulate educational goals that the teacher should implement when conducting such classes on inverse and incorrect tasks.

In these classes, students will get acquainted with the problem of humanitarization of applied mathematics education, with the problem of moral responsibility to society for the consequences of practical implementation of applied research, which requires humanitarian analysis with the participation of humanitarians $[7 ; 16-18])$.

The development of students' ICT competence as a result of learning inverse and ill-posed problems is ensured by how successfully pedagogical technologies will be implemented in practice, including:

1) attracting such specialists in the field of inverse and incorrect problems who have experience in using computer technologies in the study of inverse and incorrect problems;

2) conducting lectures and practical classes on inverse and ill-posed problems using modern multimedia and computer technologies;

3 ) the implementation of didactic principles of training inverse and ill-posed problems with use of electronic means of learning support;

4) attracting students to complete semester assignments, term papers, and final qualifying works in the field of inverse and ill-posed problems that would use computer technology.

Conclusion. Using fundamental knowledge on inverse and ill-posed problems, skills and abilities to independently apply computer technologies in the research of inverse and ill-posed problems, students develop professional competencies, including ICT competencies. ICT competencies will help such students in their future professional activities, which use the methods of applied mathematics to study the world around them, to successfully choose and use effective computer technologies. It is obvious that a student with ICT competence in his future professional activity as a researcher is able to successfully solve complex applied problems from different subject areas independently using modern information technologies.

Having mastered deep knowledge of inverse and ill-posed problems, having formed a humanitarian culture, students can be successful specialists in their research activities, realizing and understanding the meaning of the humane relationship of the applied activity itself with the surrounding world, nature and society, and the need to apply environmental technologies in applied research. 


\section{References}

[1] Belov YuA, Lyubanova ASh, Polynceva SV, Sorokin RV, Frolenkov IV. Obratnye zadachi matematicheskoj fiziki [Inverse problems of mathematical physics]. Krasnoyarsk: SFU Publ.; 2008.

[2] Vabishevich PN. Vychislitel'nye metody matematicheskoj fiziki. Obratnye zadachi $i$ zadachi upravleniya [Computational methods of mathematical physics. Inverse problems and management problems]. Moscow: Vuzovskaya kniga Publ.; 2019.

[3] Vatulyan AO, Belyak OA, Suhov DYu, Yavruyan OV. Obratnye i nekorrektnye zadachi [Inverse and ill-posed problems]. Rostov-on-Don: Izd-vo Yuzhnogo federal'nogo universiteta Publ.; 2011.

[4] Kornilov VS. The inverse problems in the content of training applied mathematics. Bulletin of Peoples' Friendship University of Russia. Series: Informatization in Education]. 2014;(2):109-118.

[5] Kornilov VS. Training students to inverse problems for differential equations as the factor of forming competence in the field of applied mathematics. Bulletin of Peoples' Friendship University of Russia. Series: Informatization of Education. 2015;(1):63-72.

[6] Kornilov VS. Realizaciya nauchno-obrazovatel'nogo potenciala obucheniya studentov vuzov obratnym zadacham dlya differencial'nyh uravnenij [Realization of scientific and educational potential of teaching university students inverse problems for differential equations]. Kazanskij pedagogicheskij zhurnal [Kazan pedagogical journal]. 2016; (6):55-59.

[7] Kornilov VS. Teoriya i metodika obucheniya obratnym zadacham dlya differencial'nyh uravnenij [Theory and method of teaching inverse problems for differential equations]. Moscow: OntoPrint; 2017.

[8] Petrov YuP, Sizikov VS. Korrektnye, nekorrektnye i promezhutochnye zadachi s prilozheniyami [Correct, incorrect and intermediate tasks with applications]. Saint Petersburg: Politekhnika Publ.; 2003.

[9] Romanov VG. Ustojchivost' v obratnyh zadachah [Stability in inverse problems]. Moscow: Nauchnyj mir Publ.; 2005.

[10] Grinshkun VV. Sushchestvuyushchie podhody k ispol'zovaniyu sredstv informatizacii pri obuchenii estestvennonauchnym disciplinam. Vestnik Moskovskogo gorodskogo pedagogicheskogo universiteta. Seriya: Informatika i informatizacija obrazovanija [Bulletin of the Moscow City Pedagogical University. Series: Informatics and Informatization of Education]. 2014;4 30):8-13.

[11] Boronenko TA, Fedotova VS. Formirovanie IKT-kompetentnosti nauchno-pedagogicheskih kadrov $\mathrm{v}$ trekhurovnevoj sisteme vysshego obrazovaniya [Formation of ICT competence of scientific and pedagogical personnel in the three-level system of higher education]. Obrazovanie i nauka [Education and science]. 2016;(1): 95-106.

[12] Buzhinskaya NV. Metodika ocenki urovnya IKT-kompetentnosti studentov pedagogicheskih vuzov [Methodology for assessing the level of ICT competence of students of pedagogical universities]. Vestnik Bryanskogo gosudarstvennogo universiteta [Bulletin of the Bryansk State University]. 2016;1(27):319-324.

[13] Goloskokov DP. Uravneniya matematicheskoj fiziki. Reshenie zadach v sisteme Maple [Equations of mathematical physics. Solving problems in the Maple system]. Saint Petersburg: Piter Publ.; 2004.

[14] Kornilov VS. Psychological aspects of training higher school students to fractal sets. Bulletin of Peoples' Friendship University of Russia. Series: Informatization of Education. 2011;(4):79-82.

[15] Edvards ChG., Penni DE. Differencial'nye uravneniya i kraevye zadachi: modelirovanie $i$ vychislenie s pomoshch'yu Mathematica, Maple i Matlab [Differential equations and boundary value problems: modeling and computation using Mathematica, Maple and Matlab]. Moscow: Vil'yams Publ.; 2008. 
[16] Ivashchenko AV, Gagarin AV, Stepanov SA. Cennostnyj podhod k formirovaniyu professional'no-ekologicheskoj kul'tury budushchego specialista [Value approach to the formation of professional and environmental culture of the future specialist]. Vestnik Moskovskogo gosudarstvennogo gumanitarnogo universiteta imeni M.A. Sholohova [Bulletin of the Moscow State University for the Humanities named after M.A. Sholokhov]. 2012;1(1):58-67.

[17] Muravyova EV. Ekologicheskoe obrazovanie studentov tekhnicheskogo vuza kak bazovaya sostavlyayushchaya strategii preodoleniya ekologicheskogo krizisa [Ecological education of technical university students as a basic component of the strategy for overcoming the ecological crisis] (dissertation of the doctor of pedagogical sciences). Kazan; 2008.

[18] Fajrushina SM. Formirovanie ekologicheskoj kul'tury studentov pedagogicheskih vuzov $\mathrm{v}$ processe izucheniya estestvennonauchnyh discipline [Formation of ecological culture of students of pedagogical universities in the process of studying natural science disciplines] (dissertation of the candidate of pedagogical sciences). Kazan; 2007.

\section{Список литературы}

[1] Белов Ю.А., Любанова А.Ш., Польнщева С.В., Сорокин Р.В., Фроленков И.В. Обратные задачи математической физики: учебное пособие. Красноярск: СФУ, 2008. 153 c.

[2] Вабишевич П.Н. Вычислительные методы математической физики: обратные задачи и задачи управления. М.: Вузовская книга, 2019. 478 с.

[3] Ватульян А.О., Беляк О.А., Сухов Д.Ю., Явруян О.В. Обратные и некорректные задачи: учебное пособие. Ростов-на-Дону: Изд-во Южного федерального университета, 2011. $232 \mathrm{c}$.

[4] Корнилов B.C. Обратные задачи в содержании обучения прикладной математике // Вестник Российского университета дружбы народов. Серия: Информатизация образования. 2014. № 2. С. 109-118.

[5] Корнилов В.С. Обучение студентов обратным задачам для дифференциальных уравнений как фактор формирования компетентности в области прикладной математики // Вестник Российского университета дружбы народов. Серия: Информатизация образования. 2015. № 1. С. 63-72.

[6] Корнилов В.С. Реализация научно-образовательного потенциала обучения студентов вузов обратным задачам для дифференциальных уравнений // Казанский педагогический журнал. 2016. № 6. С. 55-59.

[7] Корнилов B.C. Теория и методика обучения обратным задачам для дифференциальных уравнений: монография. М.: ОнтоПринт, 2017. 500 с.

[8] Петров Ю.П., Сизиков В.С. Корректные, некорректные и промежуточные задачи с приложениями: учебное пособие. СПб.: Политехника, 2003. 261 с.

[9] Романов В.Г. Устойчивость в обратных задачах. М.: Научный мир, 2005. 296 с.

[10] Гриншкун В.В. Существующие подходы к использованию средств информатизации при обучении естественно-научным дисциплинам // Вестник Московского городского педагогического университета. Серия: Информатика и информатизация образования. 2014. № 4 (30). С. 8-13.

[11] Бороненко Т.А., Федотова В.С. Формирование ИКТ-компетентности научнопедагогических кадров в трехуровневой системе высшего образования // Образование и наука. 2016. № 1. С. 95-106.

[12] Бужинская Н.В. Методика оценки уровня ИКТ-компетентности студентов педагогических вузов // Вестник Брянского государственного университета. 2016. № 1 (27). С. 319-324.

[13] Голоскоков Д.П. Уравнения математической физики: решение задач в системе Maple: учебник для вузов. СПб.: Питер, 2004. 539 с. 
[14] Корнилов В.С. Психологические аспекты обучения студентов вузов фрактальным множествам // Вестник Российского университета дружбы народов. Серия: Информатизация образования. 2011. № 4. С. 79-82.

[15] Эдвардс Ч.Г., Пенни Д.Э. Дифференциальные уравнения и краевые задачи: моделирование и вычисление с помощью Mathematica, Maple и Matlab: учебник. М.: Вильямс, 2008. 1097 с.

[16] Иващенко А.В., Гагарин А.В., Степанов С.А. Ценностный подход к формированию профессионально-экологической культуры будущего специалиста // Вестник Московского государственного гуманитарного университета имени М.А. Шолохова. 2012. Т. 1. № 1. С. 58-67.

[17] Муравьёва Е.В. Экологическое образование студентов технического вуза как базовая составляющая стратегии преодоления экологического кризиса: дис. ... д-ра пед. наук. Казань, 2008. 343 с.

[18] Файрушина С.М. Формирование экологической культуры студентов педагогических вузов в процессе изучения естественно-научных дисциплин: дис. .... канд. пед. наук. Казань, 2007. 217 с.

\section{Bio note:}

Viktor S. Kornilov, doctor of pedagogical sciences, candidate of physical and mathematical sciences, full professor, professor of the department of informatization of education of the Moscow City University. E-mail: vs_kornilov@mail.ru

\section{Сведения об авторе:}

Корнилов Виктор Семенович, доктор педагогических наук, кандидат физико-математических наук, профессор, профессор департамента информатизации образования Московского городского педагогического университета. E-mail: vs_kornilov@mail.ru 